\title{
Influence of Temperature on Composition of Wood Pyrolysis Products
}

\section{Utjecaj temperature na sastav proizvoda pirolize drva}

\author{
Original scientific paper • Izvorni znanstveni rad \\ Received - prispjelo: 3. 3. 2017. \\ Accepted-prihvaćeno: 1. 12. 2017. \\ UDK: $630 * 875.2$ \\ doi:10.5552/drind.2017.1714
}

\begin{abstract}
Experiments on birch wood chips of a size $<20 \mathrm{~mm}$ have been conducted in a laboratory scale batch pyrolysis reactor to study the effect of temperature on the pyrolysis product yields and the balance of elements in the products. The investigated variable was the pyrolysis temperature, which was equal to 300,400 and $500^{\circ} \mathrm{C}$ in consecutive pyrolysis runs. Products were separated into five fractions: gases, tar, water, char, and a low-boiling liquid fraction. The paper presents the mass share of each fraction as a function of temperature. The content of carbon, hydrogen and nitrogen was analysed in each fraction. The paper summarizes the weights of different fractions and the distribution of elements in each fraction. The gas fraction was analysed with the use of a gas chromatograph with thermal conductivity detector, while the liquid fraction was analysed in a gas chromatograph with mass detector. To analyse the content of $C, H$ and $N$ in tar and charcoal, an elemental analyser was used. The preformed study has revealed that the increase of the pyrolysis temperature leads to the increase of the amount of char and to the decrease of the amount of tars (heavy tars and low boiling tars). The amount of water in the pyrolysis products does not change as significantly as the amount of tars, which is the result of constant amount of water obtained in the pyrolysis process. The amount of pyrogenic water increases with the increasing temperature of the process.
\end{abstract}

Keywords: Pyrolysis, thermal decomposition, Thermogravimetric Analysis (TGA), Biomass, Bio-oil

SAŽETAK • Radi proučavanja utjecaja temperature na prinose produkata pirolize i ravnoteže elemenata u proizvodima pirolize, u laboratorijskom su reaktoru za pirolizu provedeni eksperimenti s česticama drva breze manjima od 20 $\mathrm{mm}$. Promjenjiva varijabla u eksperimentu bila je temperatura pirolize, koja je u uzastopnim ciklusima pirolize iznosila 300, 400 i $500^{\circ} \mathrm{C}$. Proizvodi pirolize razdvojeni su u pet frakcija: plinove, katran, vodu, ugljen i tekuću frakciju niskog vrelišta. U radu je prikazan maseni udio svake frakcije kao funkcije temperature. U svakoj je frakciji analiziran sadržaj ugljika, vodika i dušika. U radu su prikazani udjeli pojedinih frakcija i raspodjela elemenata u svakoj od njih. Frakcija plina analizirana je upotrebom plinskog kromatografa s detektorom toplinske vodljivosti, dok je tekuća frakcija analizirana u plinskom kromatografu s detektorom mase. Za analizu sadržaja $C, H$ i $N$ u katranu i drvenom ugljenu upotrijebljen je elementarni analizator. Provedena je studija pokazala da povećanje temperature pirolize dovodi do povećanja količine ugljena i smanjenja količine katrana (teških katrana i katrana niskog vrelišta). Količina vode u proizvodima pirolize ne mijenja se značajno s promjenom temperature, što je rezultat stalne količine vode u uzorcima, koja u procesu pirolize ispari. Količina pirogene vode povećava se s porastom temperature procesa pirolize.

Ključne riječi: piroliza, termička dekompozicija, termogravimetrijska analiza (TGA), biomasa, bioulje

\footnotetext{
${ }^{1}$ Authors are researcher at Institute of Fluid-Flow Machinery, Polish Academy of Sciences, Gdańsk, Poland. ${ }^{2}$ Author is PhD student at Gdańsk Univeristy of Technology, Faculty of Mechanical Engineering Gdańsk, Poland.

${ }^{1}$ Autori su istraživači Odsjeka za hidrauličke strojeve, Poljska akademija znanosti, Gdanjsk, Poljska. ${ }^{2}$ Autor je doktorand Tehnološkog sveučilišta u Gdanjsku, Strojarski fakultet, Gdanjsk, Poljska.
} 


\section{INTRODUCTION}

\section{UVOD}

Pyrolysis is an endothermic thermochemical process used to receive a variety of chemicals or fuels. As a result of the pyrolysis of wood, liquid, gaseous and solid products are obtained (Kardaś, 2014). The relative amount of each pyrolysis product (gas, char, liquid) can be modified by adjusting parameters of the operating process. The major operating parameters are: temperature, sweep gas flow rate, heating rate, and pressure (Akhtar, 2012). Numerous studies exhibit dramatic influence of the pyrolysis temperature on product distribution. During the pyrolysis in a solar reactor (Zeng, 2015), the gas yield increased by more than three times when the temperature increased from $600{ }^{\circ} \mathrm{C}$ to $2000{ }^{\circ} \mathrm{C}$. The maximum gas yields of $50.9 \%$ (mainly $\mathrm{CO}$ and a little of CH4) were achieved for beech wood pyrolysis at $2000{ }^{\circ} \mathrm{C}$ and $50{ }^{\circ} \mathrm{C} / \mathrm{s}$ heating rate with $6 \mathrm{Ndm}^{3} /$ min argon flow rate. The highest temperature gives the highest gas yields. The most important gas yield increases (15.3\% to $37.1 \%$ ) and liquid yield decreases (70.7\% to $51.6 \%$ ) were found between 600 and $1000{ }^{\circ} \mathrm{C}$ (Zeng, 2015). The char yield is approximately constant above $600{ }^{\circ} \mathrm{C}$ and depends on the heating rate. This is roughly between $10-30 \%$ for slow-pyrolysis and 5-20\% for fast pyrolysis (Blasi, 2009). The temperature also affects the liquid yield. Numerous works on biomass pyrolysis showed yield increase with temperature in the range $400-550{ }^{\circ} \mathrm{C}$, with further yield decrease (Bridgwater, 1999). The liquid product was composed of aqueous and bio-oil phases. The former phase, including all the watersoluble organic compounds, consists of water coming from both the moisture in the wood and the dehydration reactions taking place during the pyrolysis process (Antonakou, 2006). The main constituent of the aqueous phase was water ( $90 \mathrm{wt} \%)$. The watersoluble organic compounds were mainly acetic and formic acid, and they contained low molecularweight oxygenated organic compounds such as aldehydes, ketones, alcohols, phenols and others (Wei, 2006; Mohan, 2006). All the water-soluble organic compounds could be recovered as useful chemicals (Zhang, 2005). Yorgun (2015) presents the results of pyrolysis of paulownia wood and shows how the pyrolytic aqueous chase fraction increases with temperature. At the temperature of $623 \mathrm{~K}$, the aqueous fraction amounted to $19.9 \%$ of the product mass, while at $873 \mathrm{~K}$, it increased to $21.1 \%$. There is a large number of works addressing various process conditions and influence of these parameters on the obtained products (Wang, 2010; Septien, 2012; Yorgun, 2015). In the present paper, due to a very large number of variables influencing the pyrolysis, only one parameter was chosen for examination - temperature. Different amounts of individual pyrolysis products at different temperatures are due to the degree of thermal conversion of biomass and the reactions occurring at a given temperature.

\section{MATERIALS AND METHODS 2. MATERIJALI I METODE}

\subsection{Birch wood samples}

2.1. Uzorci drva breze

Chips of birch of a grain size $<20 \mathrm{~mm}$ were used as fuel in the experiment. The wood was analysed for its technical and elemental characteristics. The measured parameters included humidity, heat of combustion, elemental composition, ash and volatiles. The characteristics of the used fuel were important for interpretation of the obtained results. The results of the performed analysis are shown in Tab. 1.

Table 1 Technical and elemental analysis

Tablica 1. Tehnička i elementarna analiza

\begin{tabular}{|l|c|}
\hline Parameter / Veličina & Value / Vrijednost \\
\hline $\begin{array}{l}\text { Combustion heat } \\
\text { toplina izgaranja, MJ / kg }\end{array}$ & 17.37 \\
\hline Carbon / ugljik, \% & 48.81 \\
\hline Hydrogen / vodik, \% & 5.85 \\
\hline Nitrogen / dušik, \% & 0.43 \\
\hline Oxygen / kisik, \% & 42.6 \\
\hline Ash / pepeo, \% & 2.3 \\
\hline
\end{tabular}

\subsection{Experimental setup and procedures}

2.2. Provedba eksperimenta

Pyrolysis experiments were carried out in a hightemperature pyrolysis reactor ŚMIGŁY (Fig. 1.). The reactor has the shape of a cylindrical vessel with an internal diameter of $98 \mathrm{~mm}$. The active part of the reactor chamber, located in the central section, is wrapped with induction heating and thermal insulation. The upper part is a chamber with a valve spacer loading the reactor. The bottom of the active part of the reactor chamber is provided with valve spacer revision. The reactor is designed for pyrolysis at temperatures up to $950{ }^{\circ} \mathrm{C}$. The system is equipped with bleed air coolers to cool the gases discharged from the reactor. The stream of the pyrolysis gas formed in the reactor passes through the system of five scrubbers. During the experiment, the first washer worked at room temperature and was filled with isopropanol. The next four muds

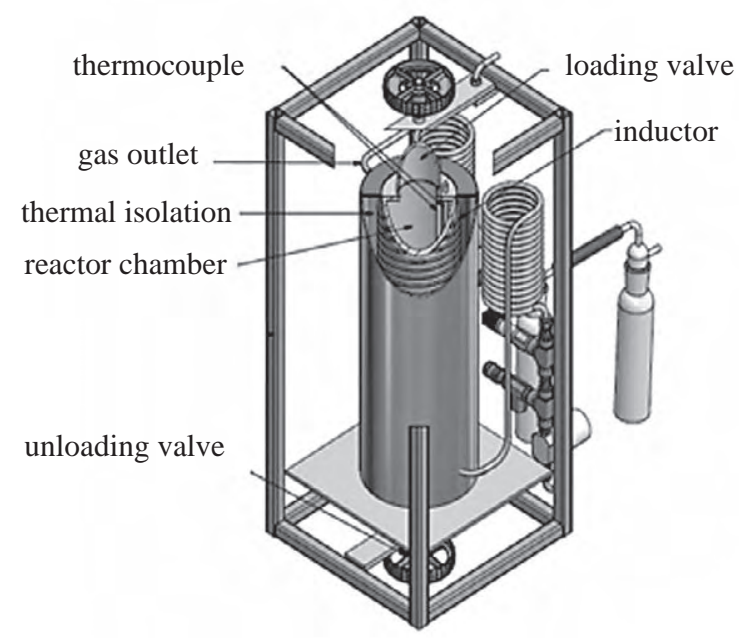

Figure 1 Pyrolysis reactor Smigly

Slika 1. Reaktor za pirolizu Smigly 


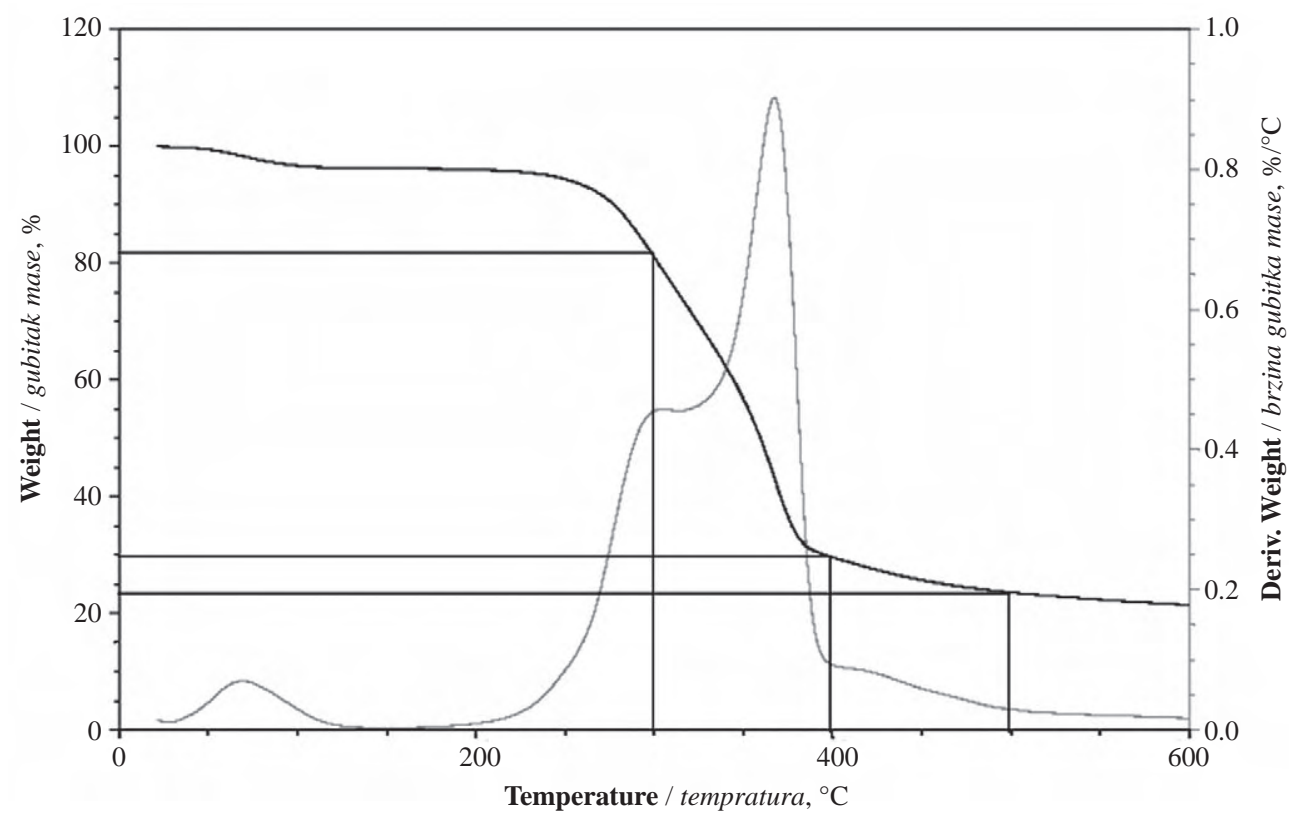

Figure 2 Thermogravimetric pyrolysis of birch wood

Slika 2. Termogravimetrijska analiza brezovine

were placed in a cryostat at $-20^{\circ} \mathrm{C}$, two of which were filled with isopropanol, while the next two were blank. The pyrolysis gas was analysed by GC-ECD. The contents of $\mathrm{CO}, \mathrm{CO}_{2}, \mathrm{H}_{2}$ and $\mathrm{CH}_{4}$ were considered in the gas analysis. Low temperatures, at which the scrubbers were kept, supported the condensation of the liquid fraction with low volatility components and protected against evaporation of the isopropanol scrubbers.

After the experiment, the contents of all fluids were pooled in a flask, the flushing was washed in isopropanol, and the washings were poured into the flask. Then the flask was refilled with fresh isopropanol to give a total volume of $0.5 \mathrm{dm}^{3}$. This procedure was used in all experiments. Next, a liquid sample was analysed for water content using a Carl-Fischer titrator. Another sample of the liquid was placed in a tarred glass evaporator, reweighed and left under the hood until the isopropanol, water and low-boiling fractions evaporated. The remaining fraction, here denoted as heavy tar, was weighed and then analysed in terms of combustion heat, and the contents of $\mathrm{H}, \mathrm{N}$ and $\mathrm{C}$. Once the reactor had cooled, another solid fraction - char, was unloaded. This fraction was also weighed and examined in terms of heat content. The gaseous fraction was determined by chromatography, and its calorific value was calculated from the composition of the pyrolysis gas.

\subsection{Results of thermogravimetric analysis}

\subsection{Rezultati termogravimetrijske analize}

In order to plan the experiment in the pyrolysis reactor, preliminary experiments were performed in a thermogravimetric analyser. Figure 2 presents a graph of thermogravimetric pyrolysis of birch wood. The graph shows the weight change with temperature. The most intense degassing can be noticed for the temperature of $370^{\circ} \mathrm{C}$. The figure also presents the derivative weight of the temperature. In the graph, points correspond to the discharge of solid residue at the temperature at which the experiments were conducted in the pyrolysis reactor. For the temperatures of 300,400 and $500{ }^{\circ} \mathrm{C}$, the solid residue was 82,29 and $23 \%$ of the initial mass, respectively. The most intensive degassing was $0.9 \%$ of weight $/{ }^{\circ} \mathrm{C}$ and applied to the temperature of $370^{\circ} \mathrm{C}$. The TGA studies are the introduction to the experimental research. They provide the information on the temperature at which the pyrolysis of wood starts and on pyrolysis residues at specific temperatures. However, these studies do not answer the question what products are obtained during the pyrolysis.

\section{RESULTS}

\section{REZULTAT}

\subsection{Pyrolysis runs to $300{ }^{\circ} \mathrm{C}$}

3.1. Piroliza pri $300^{\circ} \mathrm{C}$

Products of the pyrolysis of birch chips at $300^{\circ} \mathrm{C}$ were divided into five fractions, which were in three states of matter: solid - char, gas - pyrolysis gas, and liquid - water, heavy tars, and low-boiling liquids. The percentage of each fraction is presented in Fig. 3. The

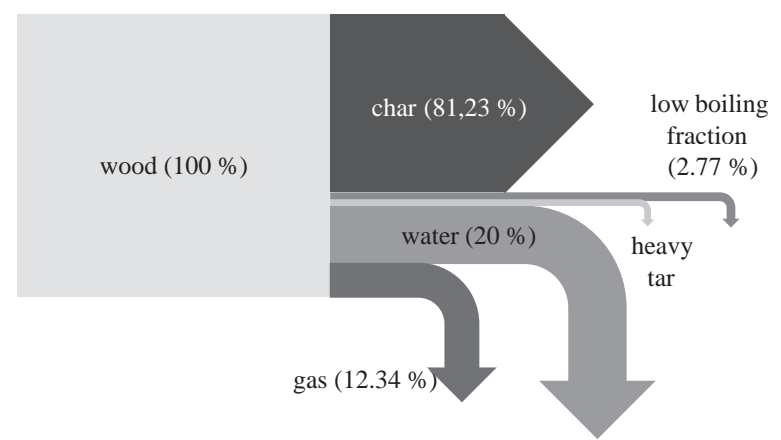

Figure 3 Share of each fraction obtained below $300{ }^{\circ} \mathrm{C}$, presented as the Sankey diagram

Slika 3. Udjeli pojedinih frakcija dobivenih pri temperaturi pirolize nižoj od $300{ }^{\circ} \mathrm{C}$ prikazani kao Senkijev dijagram 


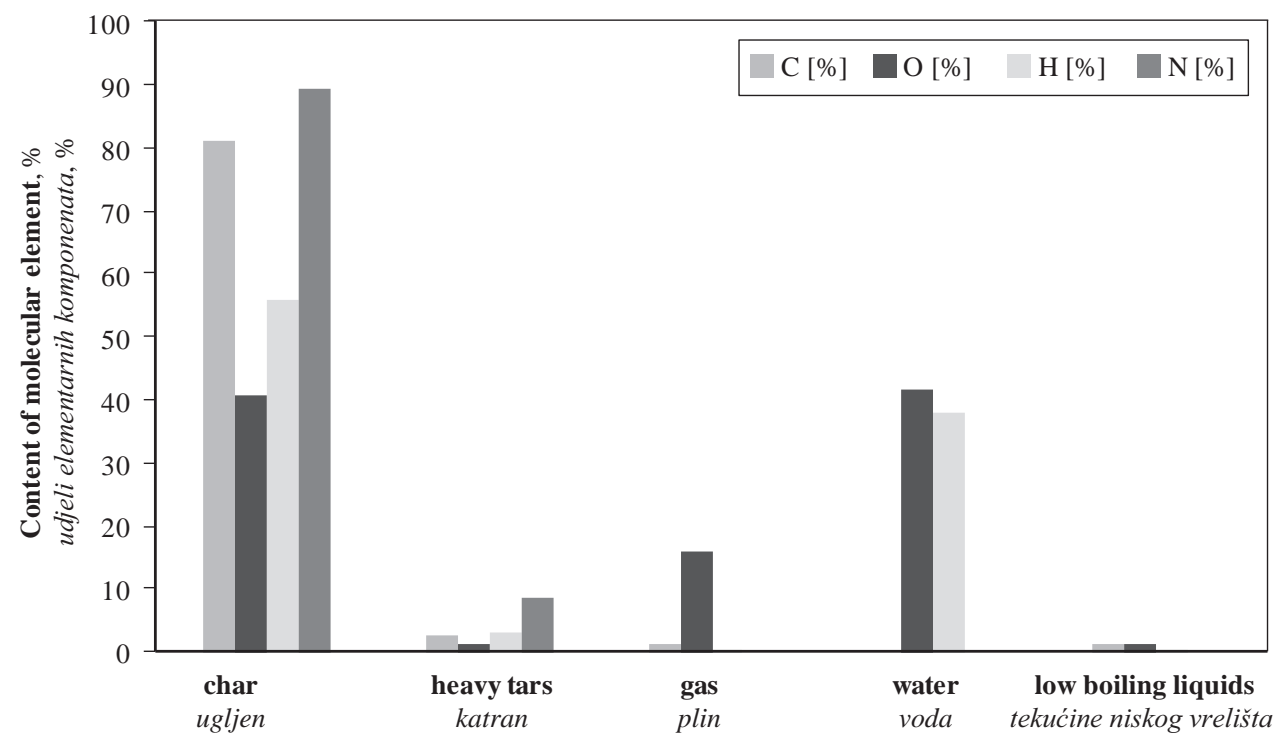

Figure 4 Contributions of individual elementary components $(\mathrm{C}, \mathrm{O}, \mathrm{H}, \mathrm{N})$ in the products of pyrolysis at $300{ }^{\circ} \mathrm{C}$ Slika 4. Udjeli pojedinih elementarnih komponenata $(\mathrm{C}, \mathrm{O}, \mathrm{H}, \mathrm{N})$ u proizvodima pirolize pri $300^{\circ} \mathrm{C}$

main product obtained was char, representing $62.86 \%$ of weight, with $63.07 \%$ carbon content. The char contained more than $81 \%$ elemental carbon in the wood before the trial. The solid fraction contained the greater part of nitrogen in the wood (89\%) and $55 \%$ of hydrogen. The remaining nitrogen was mostly contained in heavy tars $(8.58 \%)$. A large part of hydrogen in the timber constituted water hydrogen, present as the moisture condensed out with the liquid fraction (38\%). The obtained fraction was characterized by the combustion heat slightly greater than that of the wood used for the experiments $(17.37 \mathrm{MJ} / \mathrm{kg}$ ) and amounting to $18.84 \mathrm{MJ} / \mathrm{kg}$. The determination of the water content in the products showed the increase of 20 grams of water per 100 grams of timber sample. The amount of tar obtained in the experiment was low and amounted to lowboiling liquids and heavy tars, with 2 and $3 \%$ contents, respectively. Figure 4 presents the contributions of individual elementary components $(\mathrm{C}, \mathrm{O}, \mathrm{H}, \mathrm{N})$ in the products of pyrolysis.

The main combustible components in the pyrolysis gas are hydrogen, carbon monoxide and methane. In the experiments carried out at the temperature of $300^{\circ} \mathrm{C}$, low content of combustible gases was recorded. The average calorific value of the pyrolysis gas was $1.57 \mathrm{MJ} / \mathrm{Nm}^{3}$.

\subsection{Pyrolysis runs to $400^{\circ} \mathrm{C}$}

3.2. Piroliza pri $400{ }^{\circ} \mathrm{C}$

In a series of experiments at $400{ }^{\circ} \mathrm{C}$, the share of char decreased in relation to the lower temperature and accounted for $34 \%$ of the products. However, the content of carbon in the char increased to $78 \%$. The solids were up to $54 \%$ of the biomass carbon. To a lesser extent, elemental carbon was stored in heavy tars (16.3 $\%)$ and in pyrolysis gas $(10 \%)$. At the expense of smaller amount of solid residue, the share of other fractions increased. Half of the hydrogen (49.3\%) contained in the fuel becomes water. The hydrogen in the char and heavy tars spread out evenly and amounted to
$17.8 \%$ and $17.3 \%$. Nitrogen, similarly to the experiment at $300{ }^{\circ} \mathrm{C}$, was mainly concentrated in the char, in which $78.4 \%$ of the nitrogen from the fuel was recorded. Mass shares of individual fractions of the pyrolysis products are presented in Fig. 5, while the distributions of carbon, oxygen, hydrogen and nitrogen in the products of pyrolysis are shown in Fig. 6. In the studies of pyrolysis at $400{ }^{\circ} \mathrm{C}$, more than $30 \%$ of flammable gases were recorded. The main combustible gas was carbon monoxide. The average calorific value of the gas mixture was $4.23 \mathrm{MJ} / \mathrm{Nm}^{3}$.

\subsection{Pyrolysis runs to $500{ }^{\circ} \mathrm{C}$}

\subsection{Piroliza pri $500{ }^{\circ} \mathrm{C}$}

The pyrolysis carried out at $500^{\circ} \mathrm{C}$ resulted in a small amount of solid fraction (28\%) with high carbon content, and a large amount of liquid fraction. The solid fraction mainly consisted of carbon, constituting $85 \%$ of its weight, and contained $48.95 \%$ of the biomass carbon. Carbon substantially ended as heavy $\operatorname{tar}(35 \%)$ and, to a lesser extent, as the pyrolysis gas and low boiling liquid fraction (about $5 \%$ ). The total yield of liquid products was $62 \%$ of the substrate mass. The main components of the liquid

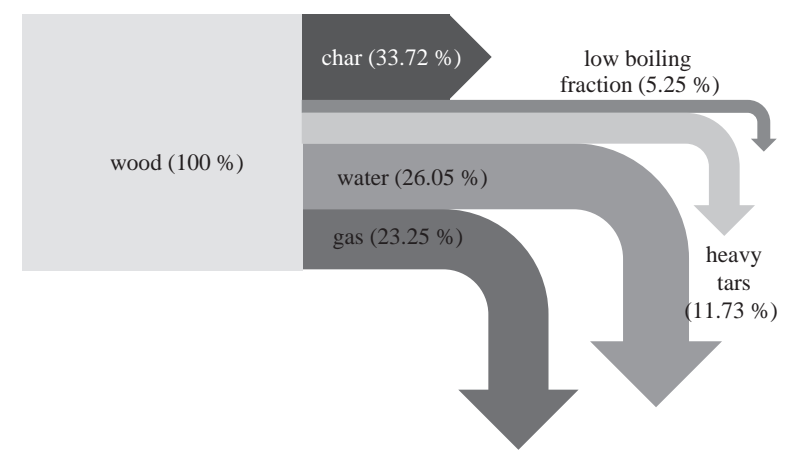

Figure 5 Share of each fraction obtained below $400{ }^{\circ} \mathrm{C}$, presented as the Senkey diagram

Slika 5. Udjeli pojedinih frakcija dobivenih pri temperature pirolize nižoj od $400{ }^{\circ} \mathrm{C}$ prikazani kao Senkijev dijagram 


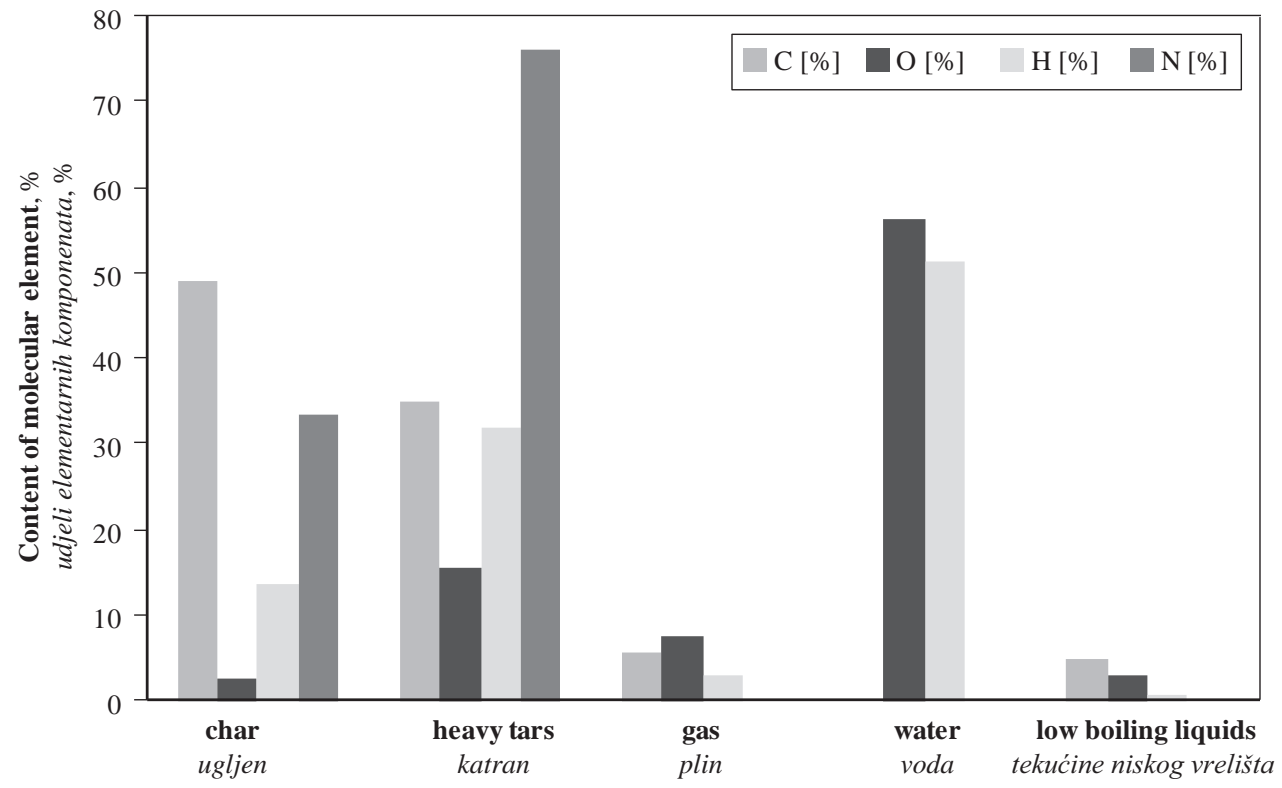

Figure 6 Contributions of individual elementary components $(\mathrm{C}, \mathrm{O}, \mathrm{H}, \mathrm{N})$ in the products of pyrolysis at $400{ }^{\circ} \mathrm{C}$ Slika 6. Udjeli pojedinih elementarnih komponenata $(\mathrm{C}, \mathrm{O}, \mathrm{H}, \mathrm{N})$ u proizvodima pirolize pri $400{ }^{\circ} \mathrm{C}$

fraction were: water (27\%), heavy tar (26\%), and low boiling liquid ( $9 \%$ ). $50 \%$ of the biomass hydrogen was in the water after the process, as in the experiment at $400{ }^{\circ} \mathrm{C}$. Additional $32 \%$ of the hydrogen from the fuel was in heavy tars. The char contained only $13 \%$ of the hydrogen from the fuel. Most of the biomass nitrogen was in heavy tars (76 \%). The remaining nitrogen was in the char. Mass shares of individual fractions of pyrolysis products are presented in Fig. 7, while the distributions of carbon, oxygen, hydrogen and nitrogen in the products of pyrolysis are shown in Fig. 8.

The experiments carried out at $500{ }^{\circ} \mathrm{C}$ were characterized by large amounts of hydrogen in the pyrolysis gas. Its average calorific value was $5.26 \mathrm{MJ} / \mathrm{Nm}^{3}$.

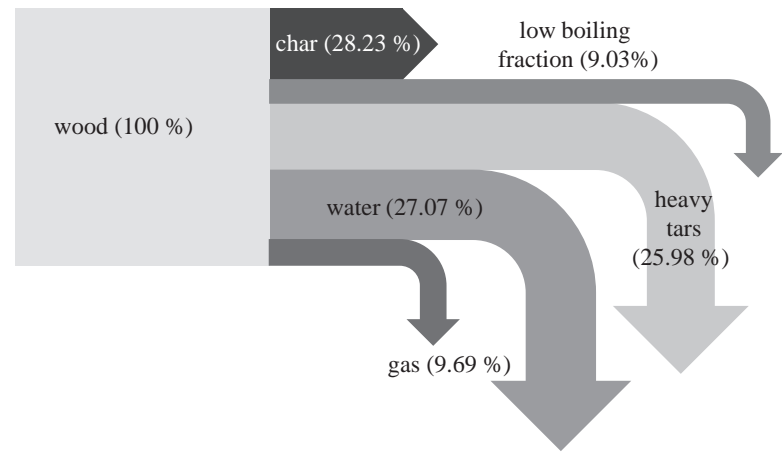

Figure 7 Share of each fraction obtained below $500{ }^{\circ} \mathrm{C}$, presented as the Senkey diagram

Slika 7. Udjeli pojedinih frakcija dobivenih pri temperaturi pirolize nižoj od $500{ }^{\circ} \mathrm{C}$ prikazani kao Senkijev dijagram

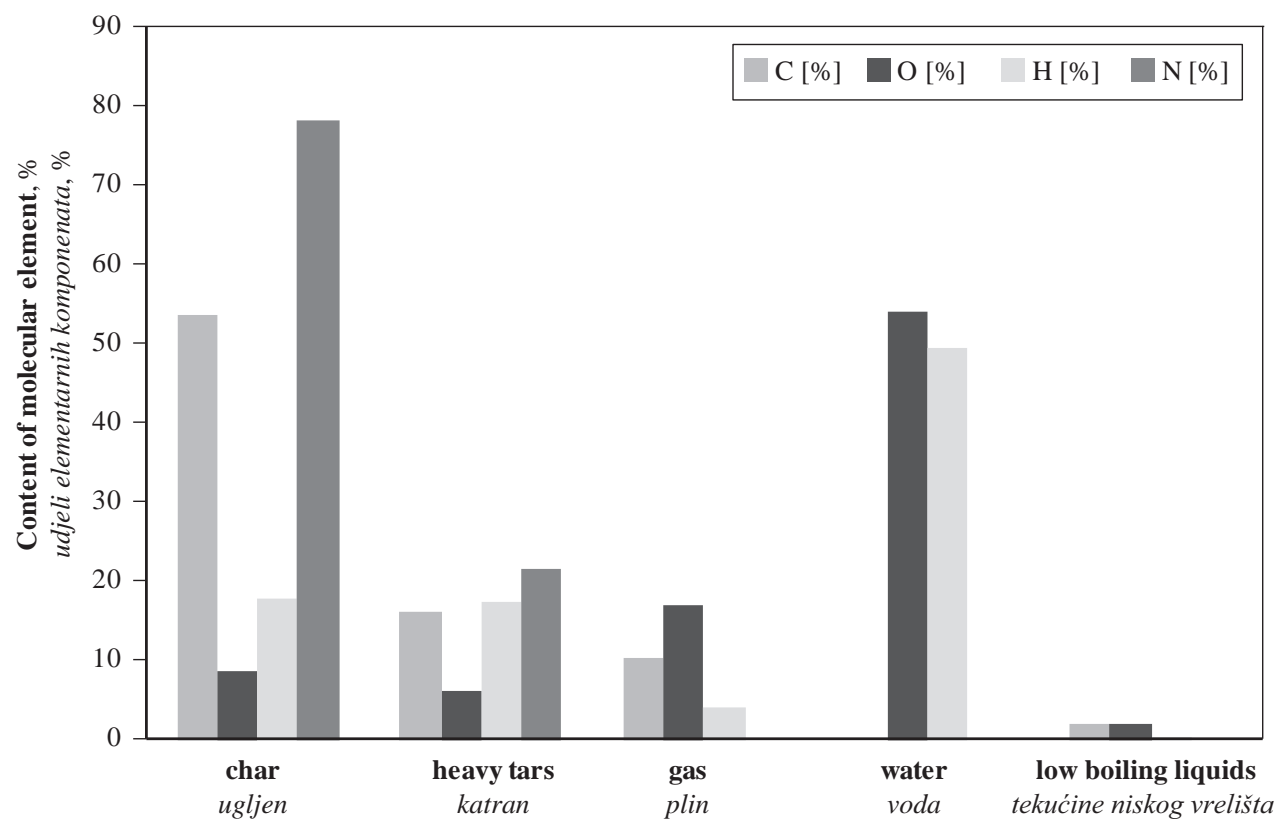

Figure 8 Contributions of individual elementary components $(\mathrm{C}, \mathrm{O}, \mathrm{H}, \mathrm{N})$ in the products of pyrolysis at $500{ }^{\circ} \mathrm{C}$ Slika 8. Udjeli pojedinih elementarnih komponenata $(\mathrm{C}, \mathrm{O}, \mathrm{H}, \mathrm{N})$ u proizvodima pirolize pri $500{ }^{\circ} \mathrm{C}$ 


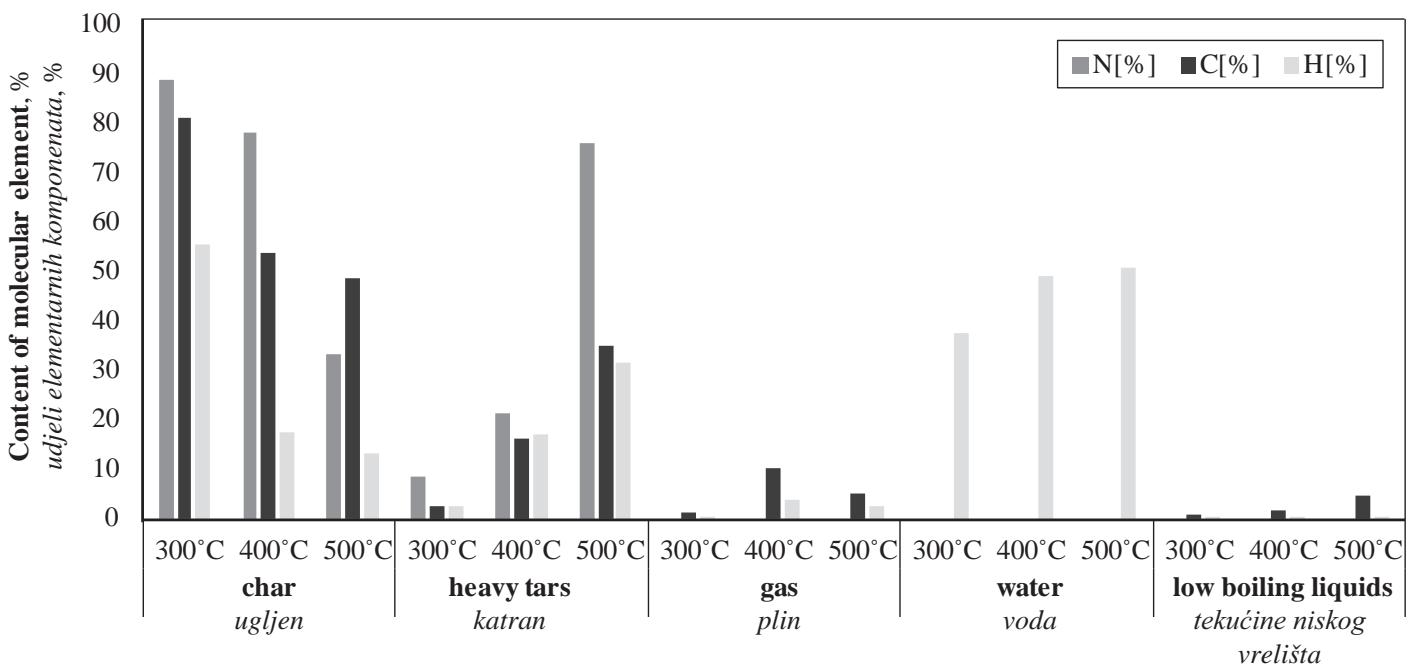

Figure 9 Contributions of individual elementary components (C, H, N) in the products of pyrolysis at 300,400 and $500{ }^{\circ} \mathrm{C}$ Slika 9. Udjeli pojedinih elementarnih komponenata (C, O, H, N) u proizvodima pirolize pri 300, 400 i $500{ }^{\circ} \mathrm{C}$

The content of combustible components in the pyrolysis gas is shown in Tab. 3.

\section{CONCLUSIONS}

4. ZAKLJUČAK

The contributions of individual fractions of the products obtained during the pyrolysis of wood biomass vary with temperature. The tendency to produce more liquid fraction and smaller amounts of char with the increasing temperature is clearly visible. Changes are also visible in the elemental composition of the pyrolysis products.

The diagram in Fig. 9 compares the percentages of pyrolysis products obtained for three temperatures of the process.

The char obtained at the highest temperature had higher carbon content and lower content of hydrogen. The calorific value of the pyrolysis gas increased with temperature, as well as the contents of hydrogen and methane in the gas mixture. At lower temperatures, most of the carbon in the timber was concentrated in the char; however, at higher temperatures, the share of carbon changed. As the temperature increased, more carbon entered into heavy tars, gases and low-boiling liquid fraction. With the increasing temperature, the concentration of nitrogen decreased in the char, increasingly going to the heavy tar. A large part of hydrogen, independently of the temperature, was in the water (from $38 \%$ at $300{ }^{\circ} \mathrm{C}$ to $51 \%$ at $500{ }^{\circ} \mathrm{C}$ ). The remaining hydrogen was initially mainly concentrated in the char. As the temperature increased, the total mass of hydrogen in the char decreased, while the hydrogen mass contained in heavy tars increased.

The aim of the research is to better understand the process in order to better design industrial installations. Pyrolysis is one of the stages occurring during gasification. The major problem of gasification is the formation of liquid pyrolysis products. Gas generator must be cleaned for further use. Good understanding of the process and knowledge of its pyrolysis products can help with gas purification and provide better design of process parameters.

\section{REFERENCES}

5. LITERATURA

1. Akhtar, J., 2012: A review on operating parameters for optimum liquid. Renewable and Sustainable Energy Reviews, 16: 5101-5109.

https://doi.org/10.1016/j.rser.2012.05.033

2. Blasi, C., 2009: Combustion and gasification rates of lignocellulosic chars. Progress in Energy and Combustion Science, 35: 121-140. https://doi.org/10.1016/j.pecs.2008.08.001

3. Bridgwater, A.; Meier, D.; Radlein, D., 1999: An overview of fast pyrolysis of biomass. Organic Geochemistry, 30: 1479-1493. https://doi.org/10.1016/S0146-6380(99)00120-5

4. Mohan, D.; Pittman, C.; Steeles, P., 2006: Pyrolysis of wood/biomass for bio-oil: a critical review. Energy Fuel, 20: 848-889. https://doi.org/10.1021/ef0502397

5. E. Antonakou, A. L., 2006: Evaluation of various types of AL-MCM-41 materials as catalysts in biomass pyrolysis for the production of bio-fuels and chemicals. Fuel, 85: 2202-2212.

https://doi.org/10.1016/j.fuel.2006.03.021

6. Zeng, K.; Flamant, G.; Gauthier, D.; Guillot, E., 2015: Solar pyrolysis of wood in a lab-scale solar reactor: influence of temperature and sweep gas flow rate on products distribution. Energy Procedia , 69: 1849-1858. https://doi.org/10.1016/j.egypro.2015.03.163

7. Wei, L.; Xu, S.; Zhang, H.; Zhu, L.; Liu, S., 2006: Characteristics of fast pyrolysis of biomass in a free fall reactor. Fuel Process Technology, 87: 863-871.

https://doi.org/10.1016/j.fuproc.2006.06.002

8. Zhang, S.; Yan, Y.; Li, T.; Ren, Z., 2005. Upgrading of liquid fuel from the pyrolysis of biomass. Bioresour. Technol., 25: 235-255. https://doi.org/10.1016/j.biortech.2004.06.015

9. Yorgun, S.; Yildiz, D., 2015: Slow pyrolysis of paulownia wood: Effects of pyrolysis parameters on product yields and bio-oil characterization. Journal of Analytical and Applied Pyrolysis, 114:68-78.

https://doi.org/10.1016/j.jaap.2015.05.003 
10. Wang, Z.; Wang, F.; Cao, J., 2010: Pyrolysis of pine wood in a slowly heating fixed-bed reactor: Potassium carbonate versus calcium hydroxide as a catalyst. Fuel Processing Technology, 91 (8): 942-950.

https://doi.org/10.1016/j.fuproc.2009.09.015

11. Septien, S.; Valin, S.; Dupont, C.; Peryot, M.; Salvador, M., 2012: Effect of particle size and temperature on woody biomass fast pyrolysis at high temperature (1000 - $\left.1400{ }^{\circ} \mathrm{C}\right)$. Fuel, 97: 202-210.

https://doi.org/10.1016/j.fuel.2012.01.049

12. Young-Kwon, P.; Myung, L.; Hyung, W.; Sung, H.; Sang-Chul, J.; Sang-Sook, P.; Sang-Chai, K., 2012: Effects of operation conditions on pyrolysis characteristics of agricultural residues. Renewable Energy, 42: 125-130. https://doi.org/10.1016/j.renene.2011.08.050

13. Sanna, A.; Li, S.; Linforth, R.; Smart, K.; Andresen, J., 2011: Bio-oil and bio-char from low temperature pyrolysis of spent grains using activated alumina. Bioresource Technol., 102 (22): 10695-10703.

https://doi.org/10.1016/j.biortech.2011.08.092
14. Yorgun, S.; Yıldız, D., 2015: Slow pyrolysis of paulownia wood: Effects of pyrolysis parameters on product yields and bio-oil characterization. Journal of Analytical and Applied Pyrolysis, 114: 68-78.

https://doi.org/10.1016/j.jaap.2015.05.003

\section{Corresponding address:}

\section{Sc. Eng. PAWEŁ KAZIMIERSKI}

Institute of Fluid-Flow Machinery

Polish Academy of Sciences

Fiszera St 14

80-231 Gdańsk, POLAND

e-mail: pkazimierski@imp.gda.pl 